\section{Antiretroviral manufacturers and the challenge of universal access to drugs through the Brazilian National STD/AIDS Program}

\author{
As empresas produtoras de anti-retrovirais e o \\ desafio do acesso universal aos medicamentos \\ do Programa Nacional de DST e AIDS
}

\author{
1 Universidade Federal do \\ Rio de Janeiro, Rio de Janeiro, \\ Brasil. \\ 2 Escola Nacional de Saúde \\ Pública Sergio Arouca, \\ Fundação Oswaldo Cruz, \\ Rio de Janeiro, Brasil. \\ Correspondence \\ R. F. Lago \\ Departamento de Medicina \\ Preventiva, Hospital \\ Universitário Clementino \\ Fraga Filho, Universidade \\ Federal do Rio de Janeiro. \\ Rua Rodolpho Paulo Rocco \\ 255, 1o andar, Cidade \\ Universitária, Rio de Janeiro, \\ RJ 21941-913, Brasil. \\ regina.ferro.lago@gmail.com
}

\section{Abstract}

This article describes the antiretroviral (ARV) manufacturing market in Brazil and contextualizes the challenges for the public policy of supplying ARVs through the National STD/AIDS Program. Increasing expenditure on these drugs is the main source of uncertainty for the policy's future. Brazil's domestic scenario is one of growing external dependence, both for the finished drugs and the active ingredients. Experience in the $\mathrm{Na}$ tional Program has shown that it is the state's role to provide public goods, which presupposes ensuring mutual compatibility between company interests and social interests. This balance is currently at stake in Brazil, since structural changes in the market have raised challenges for the National Program's sustainability, requiring new public policy instruments in defense of the collective interest. The article drew on a literature review, using bibliographic indexing sources, systematic organization of primary data, government publications, relevant legislation, research reports, and articles recommended by experts from the field.

Anti-Retrovirals Agents; Pharmaceutical Services; Drug Industry
Regina Ferro do Lago 1

Nilson do Rosário Costa 2

\section{Introduction}

The Brazilian policy for HIV/AIDS control is known worldwide for its plurality of interventions, including prevention, institutional network capacity-building, social participation, respect for human rights, and provision of antiretroviral drugs (ARV). There are now an estimated 600 thousand individuals living with HIV/AIDS in Brazil, of whom 180 thousand are receiving antiretroviral therapy (ARVT). Some 20 thousand persons begin treatment each year 1 .

In 1996, Brazilian Federal Law 9.3132 provided for universal and free access to combination ARV therapy. The bill was based on the 1988 Federal Constitution, which created the Unified National Health System (SUS) and defined health as a citizen's right. As of 2008, 18 drugs were provided in different preparations. Of these, eight (zidovudine, stavudine, didanosine, lamivudine, ritonavir, saquinavir, indinavir, and nevirapine) are manufactured domestically and ten are imported (abacavir, didanosine EC, tenofovir, amprenavir, fosamprenavir, lopinavir/r, atazanavir, efavirenz, enfuvirtide, and darunavir).

As of early 2007, the Brazilian government's strategies to guarantee the program's drug supply included domestic production of off-patent ARVs and the threat of compulsory licensing for patented drugs. More recent events like threats of compulsory licensing of efavirenz in 2007 have marked the reorientation of government action. 
These changes have been confirmed by Brazilian agenda-setters and official government documents 3,4,5. Other trends have emerged, and the government's supply of ARVs and the various stakeholders have increasingly appeared in the debates in light of this new institutional context.

The current article aims to describe the ARV manufacturing market in Brazil and identify the principal challenges for public policy and universal provision of ARVs in the National STD/AIDS Program. The article expands the discussion on the pharmaceutical market, approached in passing in the paper Dilemmas for Antiretroviral Distribution Policy in Brazil 6, which analyzed the Brazilian AIDS program as a public policy.

The key issue analyzed in this paper is that for national economies, the market for AIDS drugs reproduces the main barriers found in the overall pharmaceutical market. Typical flaws in the pharmaceutical market favor large manufacturers, which exert pressure on price formation and wield sufficient power to affect national policies, as in the case of ARV supply in Brazil.

The article consists of two sections. The first describes the overall pharmaceutical industry, an oligopoly dominated by large companies. The second section analyzes recent trends in the ARV market in Brazil, in which the transnational companies have been expanding their share.

We conducted a literature review through indexing sources such as the Sergio Arouca National School of Public Health/Oswaldo Cruz Foundation (ENSP/FIOCRUZ), the Virtual Health Library (BVS) of the Brazilian Ministry of Health, Latin American and Caribbean Health Sciences (LILACS), Scientific Electronic Library Online (SciELO), PubMed, publications by the National STD/AIDS Program, and the Brazilian National Economic and Social Development Bank (BNDES). We also consulted the relevant legislation, research reports, and articles recommended by experts from the field. The data on trends in drug purchases by the National STD/AIDS Program refer to the period 2001-2006, based on the database of the Department of Strategic Health Programs, General Coordination of Programs and Projects, Ministry of Health.

\section{The pharmaceutical market}

The pharmaceutical market is dominated by a handful of multinational companies. As emphasized by Palmeira Filho \& Pan 7, the large companies have grown rapidly since the 1940s, taking advantage of the opportunities created by advances in knowledge on chemical synthesis applied for medicinal purposes. The expansion of these companies is characterized by investment in research and development $(\mathrm{R} \& \mathrm{D})$ for new molecules, which allowed launching numerous new products, sales promotion of new drugs, and the establishment of manufacturing plants near the consumer markets.

The active ingredients used by global pharmaceutical companies used to be produced in their own centralized facilities. Since the mid1980s, intensification of international competition has led to a restructuring process in the multinational companies, which have rationalized their production by closing smaller and less efficient units and strengthening others ${ }^{8}$. This trend has intensified since the 1990s, with mergers and acquisitions. In 2006, the ten largest companies detained $47 \%$ of the industry's sales ${ }^{9}$, accompanied by a concentration of products. In that same year, the ten most widely sold drugs in the world accounted for US\$ 60 billion in total sales 9 .

The pharmaceutical industry has a concentrated, oligopolistic market structure, subject to entry barriers in the form of patent protection, the need for high investments in $R \& D$, control of the supply of active ingredients, and brand name loyalty to the leading laboratories. Particularly in the case of drugs sold under medical prescriptions, various flaws limit competition in the pharmaceutical markets, as described by Rêgo 10 \& Bastos 11:

(a) The existence of oligopolies and monopolies: no company alone controls a large share of the market. However, there is a concentration according to therapeutic class, with oligopolies and monopolies in these classes. From the consumer's point of view, this occurs because the classes do not substitute for each other, i.e., a lipid-lowering drug does not replace an antibiotic, and vice versa. The pharmaceutical companies' competitive strategy is not price competition, but the introduction of new or improved products. The competitive pattern centered heavily on innovation generates excessive dependence of the industry on $R \& D$ and marketing focused on convincing physicians to prescribe the drugs.

(b) Asymmetry of information: as in other markets for goods and services in health, information between buyers and sellers is asymmetrical.

(c) Separation of decisions on prescription, consumption, and financing: generally speaking, the consumer does not choose the product, which is prescribed by a physician. The physician (who decides) is not responsible for payment. Government or private health insurance often makes the payment, so that the classical price-based mechanism involved in the decision to consume fails to occur. 
(d) Patent protection: although drug development depends on large investments in $R \& D$, there are no relevant natural or technical barriers to the entry of new competitors, and the technologies are easy to copy in certain production phases. The industry thus requires institutional barriers that allow an innovative company to enjoy a monopoly over its processes and products for a given period of time.

(e) Brand loyalty: allows companies to maintain market niches, even after patent expiration, or after the introduction of products similar to theirs, even if improved.

These market flaws limit competition and give large companies strong market positions. Such companies thus have ample power for price-setting and the capacity to influence public policies for access to medicines.

Since it is heavily based on knowledge-intensive sectors, the pharmaceutical industry is defined as science-based, and its motor force is innovation. Partnership with a large number of public and private research institutions is essential 12 . The industry has been characterized by innovation, and major companies have succeeded in dealing with the technological revolutions experienced by the industry.

Highly innovative medicines, namely those with a new active ingredient and that provide actual clinical improvement, are less frequent and more profitable. However, so-called incremental innovations have been more common, that is, modest alterations in relation to the existing product and which present improvements as to the therapeutic effect, adverse events, dose regimen, or price. These are the so-called "me-too" drugs ${ }^{13}$. There is disagreement in the literature and decision-makers as to whether these drugs are truly innovative 14. Currently, in both the developed and developing countries, fewer and fewer companies are conducting $R \& D$ activities. In addition to the high risk and complexity of innovation processes, the increase in regulatory requirements has inflated the costs of $R \& D 15$. It has become cheaper to invest in incremental innovations, whose patent applications can be filed after the patent on the original drug expires, thus extending the patent-holder's monopoly period.

Patents are one of the principal mechanisms for private appropriation of innovations in the industry. In the case of the pharmaceutical industry, patents are viewed as essential for stimulating innovations. Such protection is a comparative advantage for the company, due to large-scale use of R\&D 16. Intellectual property is also an entry barrier, maintaining oligopolies and allowing companies to charge off-competition prices.
An important characteristic of the pharmaceutical industry is its institutional relationship with the state. Stiglitz 17 discusses the role of government in the provision of public goods and highlights the state's conflictive position in situations of monopoly or oligopoly. According to the author, government should act when the market presents flaws. Stiglitz 17 lists the basic market flaws: imperfect competition, lack of public goods, negative externalities, incomplete markets, imperfect information, and unemployment and other macroeconomic disturbances. The pharmaceutical industry displays most of these flaws.

The economic literature defines government granting of patents as a market flaw, as observed in the pharmaceutical industry. While patents may encourage innovation, they also generate a monopoly position for their holders.

Even so, the implications of intellectual property protection are extremely complex when analyzed from the perspective of national development and public-private partnership. Gadelha et al. 18 emphasize that in the developed countries, health protection and promotion activities have been consistent with innovative business activities and argue that this model should be followed in Brazil:

[In the mature countries], “...the state plays a prime role in making health policies and innovation policies mutually compatible, establishing strong regulation of economic agents, in addition to the usual policies for social well-being. Meanwhile, it induces the business sector to adopt innovative strategies based on the expected profitability of investments in $R \& D$... In the Brazilian case, we identify ... a sharp disconnect between the health system and the innovation system..." 18 (p. 57).

The question here relates to the definition - in a national setting - of the winners and losers in protection for innovation. In the effort at linking the health system and the innovation system, how does one include the large multinational companies, whose comparative advantages from patent protection threaten the sustainability of public programs that depend on protected medicines?

In short, the pharmaceutical industry is one in which government intervention is essential. The market flaw of the benefit of the monopoly position granted by the patent has been expanded by the international dissemination of property rights for pharmaceutical innovation. The central question is the acceptable limit to institutional protection for patent rights, without generating public harm. 


\section{Recent trends in the Brazilian national ARV market}

From 1996 to 2008, the Brazilian national policy for ARV distribution cost more than US\$ 2 billion ${ }^{5}$. Among the results, from 1997 to 2003, AIDS mortality dropped by $40 \%$ to $70 \%$, morbidity decreased by $60 \%$, there were 360 thousand fewer hospitalizations, and 58 thousand new AIDS cases were avoided 1 . These results are associated with a nearly tenfold increase in survival following AIDS diagnosis (from 6 to 58 months) 19.

Since 2005, there was a major increase in expenditure on ARVs that interrupted the historical decline and stabilization in the epidemic that had begun in 1999. The decline from 1999 to 2001 was probably due to domestic production of offpatent ARVs, despite an increase in the number of patients. Additionally, stabilization of expenditures from 2001 to 2005 was due to negotiations to reduce the price of imported medicines, led by the Ministry of Health. The increase in ARV spending in 2005 may have been caused by purchases of imported medicines. Among the basket provided by the National STD/AIDS Program, eight drugs were manufactured domestically. The need to purchase new imported ARVs is due to the emergence of viral resistance, which requires that patients be treated with the so-called second or third-line products, protected by patents 3 , in addition to the incorporation of drugs with lower toxicity, used in the initial regimens. Imported ARVs now account for $81.6 \%$ of total expenditure 1 .

Table 1 shows the price difference between different treatment regimens used in Brazil. While maintaining zidovudine/lamivudine as the backbone therapy, to replace nevirapine (produced domestically) with atazanavir/ritonavir (atazanavir is imported) produces a difference of US\$2,145 per treatment.

The growing need to import high-cost medicines, whose production is protected by patents, imposes a new agenda on the Brazilian state in relation to the sustainability of drug production on the same basis adopted throughout the 1990s and early $21^{\text {st }}$ century.

Notwithstanding the growing access to ARVs in the developing countries in the last five years, multiplying the number of players in the international supply arena (companies, multilateral agencies, lobby groups, and foundations), ARV provision in Brazil continues to be a responsibility of the National Health System, and the solutions must be found in the public sphere.

The Brazilian government's main strategies for ensuring the treatment program's sustainability have been the domestic production of off-patent ARVs and the threat of compulsory licensing for patented products. During this experience, moments of crisis have threatened the policy's continuity, like the currency exchange devaluation in 1999 and negotiations to reduce the prices of imported drugs in 2001, 2003, and 2005. In April 2007, after long negotiations with Merck Sharp \& Domme to reduce the price of efavirenz (marketed as Stocrin), the Ministry of Health found the results less than desirable. Using one of the flexibilities of the country's Intellectual Property Law 20, the drug was ruled a public utility, after which its compulsory licensing was also declared.

ARV supply underwent two distinct phases. In the first phase, off-patent drugs were recognized in Brazil and the products could be copied freely. The second was after the Intellectual Property Law entered into force, creating patent protection. This law was enacted in the context of Brazil's joining the TRIPS agreement (Trade-Related Aspects of Intellectual Property Rights) 21, undertheWorldTradeOrganization (WTO), which regulates the standards for intellectual property law in member countries. Law 9.279/96 20 was a watershed in the policy for distribution of AIDS drugs. Entering into force in 1997, the law's effects were felt more clearly in the middle of the current decade, with the increase in expenditures on these drugs, resulting from the alternative policy imposed by the multinational pharmaceutical companies, "forcing" the entry of second and third-line ARVs 22.

The new ARVs displayed therapeutic gains. One way of including them in the basket of drugs supplied by the National Health System was for patients to subpoena for them through the courts, using the medical prescription for a drug still not available in the public system 23. Participation of the social movement in defense of ARV policy was decisive, and we are not questioning its legitimacy here. However, it is also true that access to ARVs via legal action increased the permeability of the National Health System to imported drugs.

Imported ARVs assumed huge weight in total ARV purchases. In this new context, the domestic manufacturers' leading role in the first phase of production gave way to the predominance of large pharmaceutical companies, changing the face of the ARV market in Brazil.

Figure 1 shows the drop in government laboratories' share in comparison to private companies in supplying ARVs to the National STD/AIDS Program from 2001 to 2006. Although private Brazilian companies are included in the overall tabulation of private companies, the percentagewise decrease in the share of government labora- 
Annual expenditure per patient (in US\$) for different antiretroviral regimens for adults. Brazil, 2005.

\begin{tabular}{lc}
\hline Antiretroviral regimen & Expenditure/year (US\$) \\
\hline Zidovudine-lamivudine-nevirapine & 682.00 \\
Zidovudine-lamivudine-efavirenz & $1,005.00$ \\
Zidovudine-lamivudine-lopinevir/ritonavir & $1,805.00$ \\
Tenofovir-lamivudine-nevirapine & $1,857.00$ \\
Tenofovir-lamivudine-efavirenz & $2,180.00$ \\
Zidovudine-lamivudine-atazanavir/ritonavir & $2,827.00$ \\
\hline
\end{tabular}

Source: adapted from Greco \& Simão ${ }^{1}$.

Figure 1

Percentage share of Far-Manguinhos (Oswaldo Cruz Foundation, Rio de Janeiro, Brazil), government laboratories, and private companies in the amounts of antiretroviral drugs purchased by the Brazilian National STD/AIDS Program, 2001-2006.

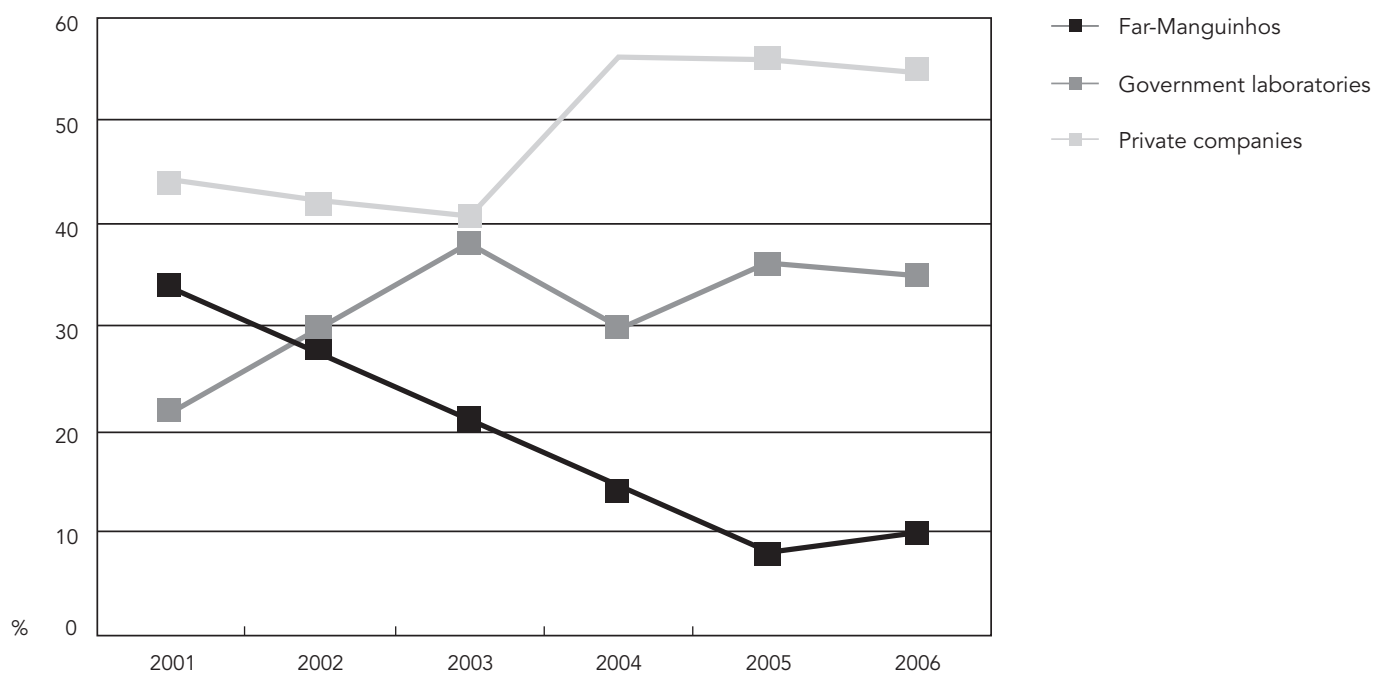

Source: prepared by the authors, based on data from the Department of Strategic Health Programs, General Coordination of Programs and Projects, Brazilian Ministry of Health.

tories is clear. Far-Manguinhos (FIOCRUZ), with an outstanding position in Figure 1, underwent a continuous and sharp decline, from $34 \%$ to $10 \%$ between 2001 and 2006. The other government laboratories began a with $22 \%$ share in 2001 . They reached their highest share in 2003, with $38 \%$, and dropped to $35 \%$ in 2006 . In 2001 , the combined share of the government laboratories was $56 \%$, with private companies accounting for the other $44 \%$. By 2006, the combined govern- ment share was $45 \%$, while the private sector had increased to $55 \%$.

As shown in Figure 2, the decrease in the National STD/AIDS Program's spending on ARVs from government laboratories is similar to the trend in the amount of drugs purchased. In 2001, Far-Manguinhos accounted for $25 \%$ of expenditures, and decreased to $4 \%$ in 2006 . The other government laboratories began with a $9.5 \%$ share of expenditures, increasing to $22 \%$ in 2003 and 
Percentage share of Far-Manguinhos (Oswaldo Cruz Foundation, Rio de Janeiro, Brazil), government laboratories, and private companies in total spending on antiretroviral drugs by the Brazilian National STD/AIDS Program, 2001-2006.

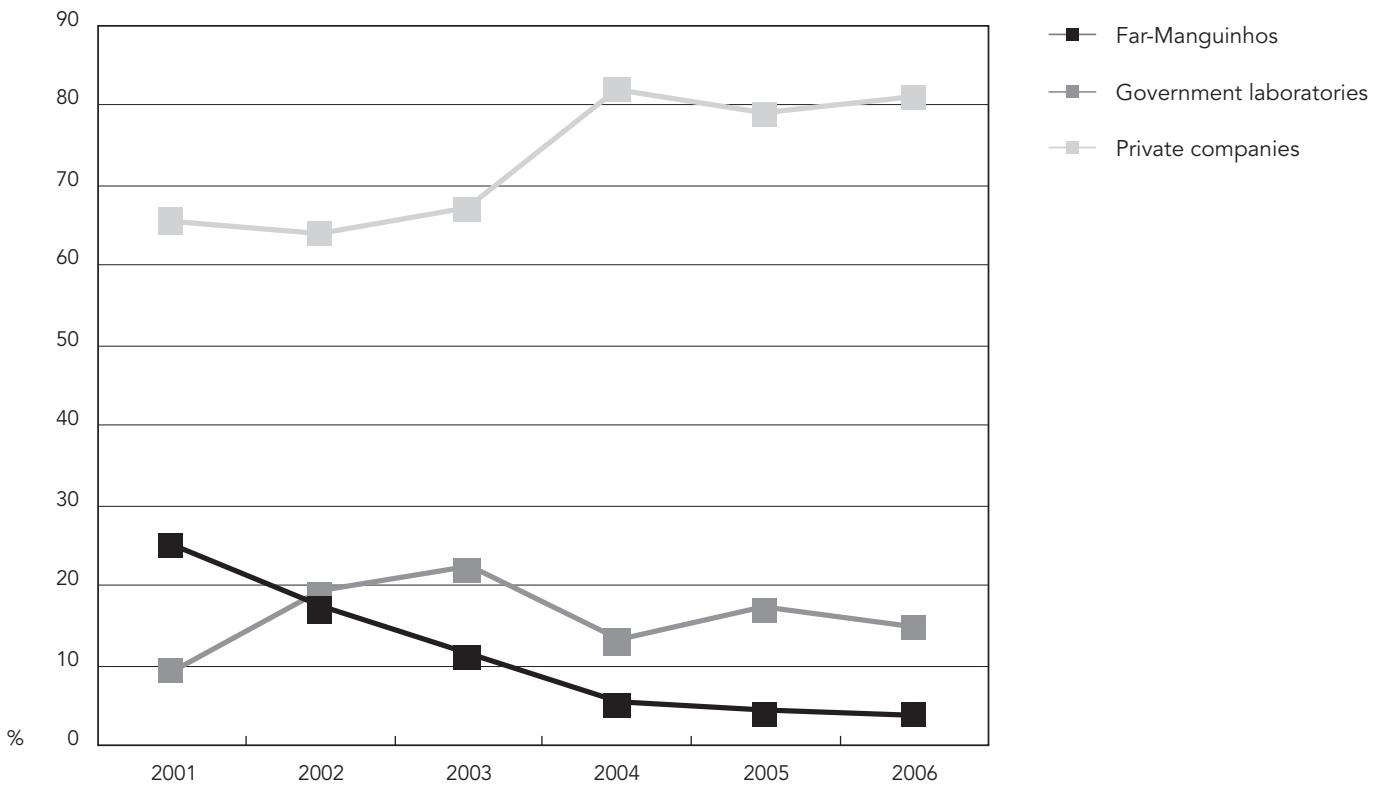

Source: prepared by the authors, based on data from the Department of Strategic Health Programs, General Coordination of Programs and Projects, Brazilian Ministry of Health.

finally dropping off to $15 \%$ in 2006 . In 2001 , the government laboratories' combined share was $34.5 \%$, while private companies accounted for $65.5 \%$. In 2006, the government laboratories' combined share dropped to $19 \%$, while the private sector increased its share to $81 \%$.

As for regulatory issues, the domestically produced ARVs that are currently distributed are classified as copies, having been registered as such with the National Health Surveillance Agency (ANVISA). ANVISA set deadlines and standards according to which copies need to be submitted to bioequivalence and bioavailability tests, among other requirements, in order to become generics. The ARVs distributed by the National Health System meet the bioequivalence and bioavailability tests, and the deadline for complying with the other ANVISA requirements is 2011.

Although there are national and foreign generic ARVs registered with ANVISA, only one generic drug is distributed in the country. Generic efavirenz (in 600mg tablets and 200mg capsules) began to be imported from the Ranbaxy laboratory of India after compulsory licensing. Its bioequivalence and bioavailability tests and pre- qualification have been approved by the World Health Organization (WHO) 24. Oral solution efavirenz is supplied by Merck. The other imported ARVs are reference drugs, protected by patents.

In the public sector, supply comes from government laboratories and is limited to drugs with expired patents. The rapid addition of new drugs by the National STD/AIDS Program led to concentration of supply, which is associated with difficulty in substituting one product with another, and segmentation occurs by therapeutic classes. In the case of ARVT, the need for the combined use of products, the combination of which is rigorously determined at the attending physician's criterion and according to each patient's clinical evolution, further limits the condition for substitution. This difficulty strengthens the market position of the large multinationals.

The global pharmaceutical companies have ample command over the private supply sector. They are brand name ARV manufacturers for products consumed in Brazil, and they control all the stages in their drugs' production chain. There are some domestic manufacturers that make finished ARVs. Few Brazilian pharmaceuti- 
cal chemical companies produce intermediate products for synthesis or use in manufacturing ARVs. This limited domestic production is sold to the government laboratories that manufacture the finished drugs. Nearly all of the intermediate products used by these laboratories are imported from China or India 4 . There is also one private Brazilian company that markets one of the foreign ARVs.

\section{The main stakeholders}

The interactions between producers of intermediate compounds and ARV manufacturers, between public and private manufacturers, between domestic and foreign manufacturers, and between all of the above and the Federal government - the only player on the demand side - are essential for understanding the dynamics of public ARV supply in Brazil.

Nongovernmental organizations and their role were beyond the scope of this analysis. However, we should highlight their relevance in supporting the policy for access to ARVs. Various authors have explored this issue, like Levi \&Victora 25 and Galvão 26, among others. The government laboratories, domestic and foreign private companies, and the Federal government are the key stakeholders for the purposes of this study and will be examined below.

\section{- Government laboratories}

As one of the pillars in the Federal government's strategy, the government laboratories are key stakeholders in ARV supply. They have a twofold mission, as the instrument for ARV price regulation and by producing low-cost drugs to expand access by the population. The public network of pharmaceutical laboratories consists of 18 laboratories affiliated with the Ministry of Health, State health secretariats, public universities, and the Armed Forces. In 2003, four of the 18 accounted for $75 \%$ of total production: Far-Manguinhos (Rio de Janeiro), Furp (São Paulo), Lifal (Alagoas), and Lafepe (Pernambuco). According to Hasenclever et al. ${ }^{15}$, most of the government laboratories have limited technological capacity and are positioned to produce finished drugs, without the integration of production and synthesis of intermediate compounds. They are thus dependent on a limited number of partners from the Brazilian private chemical industry and mainly on importation of intermediate compounds. Since they are affiliated with public institutions, they are subject to budgetary and administrative constraints. Their sales are targeted to the government, with few exceptions. According to
Frenkel 27, the exclusive commercial relations between these laboratories and the government discourage their capacity-building in pharmaceutical marketing and advertising. This is one of the limiting aspects for the operational capability of Brazilian government laboratories, as identified in the literature 28 .

For several years, the government laboratories involved in ARV manufacturing in Brazil have been Far-Manguinhos, Lafepe, Iquego (Goiás), Furp, Funed (Minas Gerais), and Lifal. Currently, Lafepe and Far-Manguinhos produce the largest number of preparations of the drugs, six and five, respectively. Although nevirapine is produced by the government laboratories, Boehringer is the only available supplier of this ARV in oral suspension.

\section{- Private Brazilian companies}

Only a few domestic private pharmaceutical companies produce active ingredients for AIDS drugs, reflecting the Brazilian pharmaceutical industry's scenario of internationalization and dependence in R\&D. Currently, Alfa Rio Química Ltda. produces intermediate compounds for Globe Química and Nortec Química S.A., which supplies the active ingredients to Far-Manguinhos. Since February 2007, production of zidovudine (100mg capsules), lamivudine (150mg tablets), and zidovudine + lamivudine (300mg + 150mg tablets) by Far-Manguinhos has used the active ingredients produced by Nortec and Globe, with traceability and quality assurance attested by follow-up of the production by technicians from Far-Manguinhos.

The Globe, Nortec, and Cristália companies are also producing the active ingredient for efavirenz in Brazil to serve Far-Manguinhos and Lafepe, which will manufacture the drug for the Ministry of Health in response to the declared compulsory licensing of this product.

Other companies have the capacity to manufacture intermediate compounds, and supplied them from 1992 to 1997, like Microbiológica QuímicaeFarmacêutica and Indústria eComércio de Medicamentos Labogen S.A., among others 4.

As for the finished drugs, Cristália has been the only private domestic pharmaceutical company to market ARVs in recent years and has vertical manufacturing capability for their production 4 .

There is also a domestically owned company, United Medical, which markets tenofovir, manufactured by Gilead Sciences Inc., which does not operate directly in Brazil.

Table 2 lists the domestically manufactured ARVs, both those produced by the government 
Antiretroviral drugs produced domestically in Brazil and type of preparation and manufacturer.

\begin{tabular}{|c|c|c|}
\hline Laboratory & Drug & Preparation \\
\hline \multirow[t]{5}{*}{ Far-Manguinhos } & Stavudine $30 \mathrm{mg}$ & Capsules \\
\hline & Lamivudine 150mg & Tablets \\
\hline & Nevirapine $200 \mathrm{mg}$ & Tablets \\
\hline & Zidovudine $100 \mathrm{mg}$ & Capsules \\
\hline & Zidovudine 300mg + lamivudine 150mg & Tablets \\
\hline \multirow[t]{2}{*}{ Funed } & Nevirapine $200 \mathrm{mg}$ & Tablets \\
\hline & Zidovudine 300mg + lamivudine 150mg & Tablets \\
\hline \multirow[t]{2}{*}{ Furp } & Lamivudine $150 \mathrm{mg}$ & Tablets \\
\hline & Zidovudine $300 \mathrm{mg}+$ lamivudine $150 \mathrm{mg}$ & Tablets \\
\hline \multirow[t]{3}{*}{ lquego } & Lamivudine oral solution & Bottle \\
\hline & Lamivudine 150mg & Tablets \\
\hline & Zidovudine $300 \mathrm{mg}+$ lamivudine $150 \mathrm{mg}$ & Tablets \\
\hline \multirow[t]{6}{*}{ Lafepe } & Didanosine powder for oral solution & Bottle \\
\hline & Stavudine $30 \mathrm{mg}$ & Capsules \\
\hline & Indinavir 400mg & Capsules \\
\hline & Zidovudine 100mg & Capsules \\
\hline & Zidovudine oral solution & Bottle \\
\hline & Zidovudine 300mg + lamivudine 150mg & Tablets \\
\hline Lifal & Indinavir 400mg & Capsules \\
\hline \multirow[t]{3}{*}{ Cristália } & Stavudine for oral solution & Bottle \\
\hline & Saquinavir $200 \mathrm{mg}$ & Capsules \\
\hline & Zidovudine Injection & Vial \\
\hline
\end{tabular}

Source: prepared by the authors based on information from the Brazilian National STD/AIDS Program, updated in August 2008.

laboratories and domestic companies, according to the National STD/AIDS Program's schedule for 2008.

\section{- Foreign private companies}

Foreign companies are present both in the importation of intermediate compounds and finished medicines.

In recent years, intermediate compounds have been acquired mostly from Chinese and Indian laboratories 4 . Part of the products imported from these countries fails to meet the required quality specifications, while the Brazilian government procurement criteria do not include quality issues, but are based on the lowest bid. Thus, the high-quality intermediate compounds from Asia are mainly targeted to countries that exercise greater control over the manufacturing conditions, which is not the case with Brazil 4.

If the winner of a tender furnishes a product that fails to meet the technical specifications, the government laboratory has the alternative of either negotiating a new batch or canceling the tender. Both options are difficult to enforce and lead to delays in delivery of the product. There have been cases in which the domestic private pharmaceutical companies have proceeded to purify the raw material in order not to jeopardize the end product's quality 4 . This situation can also increase the initial cost by up to $30 \% 29$.

Foreign private companies have a broad command over the finished product segment. The multinational pharmas sell all the brand name ARVs that are protected by patents, which account for more than $80 \%$ of the Federal spending on drugs for AIDS. Since these companies are mostly the patent-holders and sole suppliers, there is no tender, but rather price negotiation.

As for finished medicines, the generic drug efavirenz, based on the compulsory licensing declared in 2007, began to be purchased from the Indian laboratory.

Table 3 shows the imported ARVs and the suppliers, according to the National STD/AIDS Program's schedule for 2008.

\section{- Federal government}

The state's role for the pharmaceutical industry and the ARV issue is highly relevant, since the demand is essentially public and the Federal 
Antiretroviral drugs imported by Brazil, by type of preparation, trade name, and manufacturer.

\begin{tabular}{|c|c|c|c|}
\hline Laboratory & Drug & Preparation & Trade name \\
\hline \multirow[t]{4}{*}{ Glaxo SmithKline } & Abacavir 300mg & Tablets & Ziagenavir \\
\hline & Abacavir oral solution & Bottle & Ziagenavir \\
\hline & Amprenavir oral solution & Bottle & Agenerase \\
\hline & Fosamprenavir * 700mg & Tablets & Telzir \\
\hline \multirow[t]{4}{*}{ Bristol-Myers Squibb } & Atazanavir 150mg & Capsules & Reyataz \\
\hline & Atazanavir 200mg & Capsules & Reyataz \\
\hline & Didanosine EC 250 mg & Capsules & Videx EC \\
\hline & Didanosine EC 400mg & Capsules & Videx EC \\
\hline Tibotec & Darunavir 300 mg & Tablets & Prezista \\
\hline \multirow[t]{2}{*}{ Ranbaxy } & Efavirenz 200mg & Tablets & Generic \\
\hline & Efavirenz 600mg & Tablets & Generic \\
\hline Merck & Efavirenz oral solution & Bottle & Stocrin \\
\hline Roche & Enfuvirtide $90 \mathrm{mg} / \mathrm{Ml}$ & Vial & Fuzeon \\
\hline \multirow[t]{3}{*}{ Abbott } & Lopinavir/r 200mg/50mg & Tablets & Kaletra \\
\hline & Lopinavir/r oral solution & Bottle & Kaletra \\
\hline & Ritonavir 100mg & Capsules & Norvir \\
\hline Boehringer & Nevirapine oral suspension & Bottle & Viramune \\
\hline Gilead ** & Tenofovir 300mg & Tablets & Viread \\
\hline
\end{tabular}

Source: prepared by the authors, based on information from the Brazilian National STD/AIDS Program,

updated in August 2008.

* Fosamprenavir is a version of amprenavir;

** Marketed in Brazil by United Medical.

government is the sole purchaser. According to Gadelha ${ }^{30}$, the National Health System's design and the changes in the Federal government's organization in the social policy field since the 1980s consolidated the Brazilian state as the central player in health-related issues, due to its high purchasing power for goods and services, induction, regulatory control, and interaction with civil society. The state's participation in ARVs involves various areas, such as industrial policy conditions, regulation of public purchases, regulatory issues, and especially intellectual property.

In relation to the country's intellectual property regimen, the literature maintains that the policy's results were the opposite of those claimed as the basis for adopting it. According to Brazilian and international nongovernmental organizations 13 , public sector institutions 31 , and authors such as Love 32 and Bermudez et al. 33, among others, adherence to the international rules for intellectual property has deprived the developing countries of the right to adopt the patent protection regimen that would most benefit their social, economic, and technological development. This was purportedly the Brazilian situation, in which the prevailing intellectual property regimen represented a mechanism involving market reserve and inhibition of innovation rather than an incentive for direct investment, competitiveness, and increasing technology transfer. The above authors defend a reading of the Intellectual Property Law (Law 9.279/96) 20 that is more favorable to public health, through judicious granting of patents and ample use of all the law's flexibilities, including compulsory licensing when necessary and applicable.

\section{Final remarks}

This study shows that the demand for treatment with new imported ARVs grows year by year in Brazil, increasing the country's expenditures on these drugs as of the middle of the current decade. The major increase in spending for the National STD/AIDS Program is the principal source of uncertainty concerning the on-going policy of universal access to ARVs.

This shows that the Brazilian scenario is one of growing external dependence on the importation of medicines and active ingredients. Govern- 
ment laboratories concentrate the manufacturing of medicines with low technological density, demonstrating that although they were highly important during the first phase of ARV supply, they have lost their place in production volume and value, and appear incapable of dealing with the multinationals' strategy of replacing off-patent drugs with patented products.

In the second phase of the ARV distribution policy, the domestic market was substantially modified by the large pharmaceutical companies' increasing share, to the detriment of domestic manufacturers. The domestic market thus began to look more like the world ARV market, with a predominance of global pharmaceutical companies on the supply side. The prospects may be for the oligopolization of the drug supply for the Brazilian National STD/AIDS Program.

Even so, and importantly, this is still an open process. One should consider the new context of international cooperation among the emerging countries, which could create other possibilities for technological exchange and dissemination. The case of the Ministry of Health's purchase of efavirenz from Indian companies, after declaring compulsory licensing, illustrates the changes in the form of cooperation between the central and secondary economies in the current decade. The Ministry of Health has obtained extremely favorable prices for efavirenz, and a technology transfer process is under way ${ }^{34}$. However, China and India, major world producers of active ingredients and generic ARVs, recently joined the property rights rules proposed by the WTO, and the impact of this move is still not known. Will these countries experience greater dependence on the large pharmaceutical companies, as is currently happening with Brazil in relation to patented medicines? In this case, the possibilities for importing generics from these countries will also tend to decrease.

Patent rights are granted by the state and also require compensation for the market imperfections associated with the goods involved and the operational strategies by the players in these markets. While the technological barriers to copying products are surmountable, the institutional barrier imposed by the patent right itself is impeditive. The institutional barrier has become the main limitation to public policy for supplying ARVs. Price negotiation and threats of compulsory licensing gave way to a more aggressive, reactive agenda. This agenda has been consolidated in the literature and in international forums on the issue and appears to have oriented Brazil's recent decisions, especially in relation to efavirenz purchases.

The experience of the National STD/AIDS Program shows that the national state has the role of providing public goods. In some cases, the production of public goods presupposes making companies' interests and social interests mutually compatible. This balance is being challenged in Brazil, given the strengthening of the transnational companies' market position in ARV production. The National STD/AIDS Program experienced its consolidation phases based on a strategic alliance with government laboratories. Structural changes in the market created unexpected challenges for the program's sustainability, requiring new public policy instruments in defense of the collective interest.

\section{Resumo}

O artigo descreve as características do mercado produtor de anti-retrovirais no Brasil e situa os desafios para a política pública de provisão de medicamentos no Programa Nacional de DST e AIDS (PN-DST/AIDS). A elevação expressiva das despesas com esses medicamentos é a principal fonte de incerteza sobre a política. O cenário nacional é de crescente dependência externa, tanto no segmento de medicamentos quanto no de princípios ativos. A experiência do PN-DST/AIDS demonstrou que cabe ao Estado nacional a provisão de bens públicos, o que pressupõe a compatibilização entre interesses empresariais e sociais. Esse equilíbrio está sendo desafiado no Brasil visto que as mudanças estruturais no mercado trouxeram desafios à sustentabilidade do programa, exigindo novos instrumentos de política pública em defesa do interesse coletivo. Para a confecção do artigo empreendeu-se revisão da literatura usando-se fontes de indexação bibliográfica, sistematização de dados primários, publicações de órgãos públicos, legislações pertinentes, relatórios de pesquisa e artigos indicados por especialistas da área.

Anti-Retrovirais; Assistência Farmacêutica; Indústria Farmacêutica 


\section{Contributors}

R. F. Lago and N. R. Costa participated equally in all phases of the article's elaboration.

\section{References}

1. Greco D, Simão M. Brazilian policy of universal access to AIDS treatment: sustainability, challenges, and perspectives. AIDS 2007; 21 Suppl 4:S37-45.

2. Ministério da Saúde. Lei no 9.313 de 13 de novembro de 1996. Dispõe sobre a distribuição gratuita de medicamentos aos portadores do HIV e doentes de AIDS. http://www.pge.sp.gov.br/centrode estudos/bibliotecavirtual/dh/volume\%20i/saude lei9313.htm (accessed on 29/Sept/2007).

3. Grangeiro A, Teixeira L, Bastos FI, Teixeira P. Sustentabilidade da política de acesso a medicamentos anti-retrovirais no Brasil. Rev Saúde Pública 2006; 40 Suppl:60-9.

4. Orsi F, Hasenclever L, Fialho B, Tigre P, Coriat B. Intellectual property rights, anti-AIDS policy and generic drugs. In: Moatti J, Coriat B, Souteyrand Y, Barnett T, Dumoulin J, Flori YA, editors. Economics of AIDS and access to HIV/AIDS care in developing countries, issues and challenges. Paris: Agence Nationale de Recherches sur le SIDA et les Hépatites Virales; 2003. p. 110-35.

5. Ministério da Saúde. Resposta positiva 2008: a experiência do programa brasileiro de aids. http:/ /www. aids.gov.br/data/documents/storedDocuments /\%7BB8EF5DAF-23AE-4891-AD36-1903553A3174 \%7D/\%7B0CAD21C6-B31E-4358-B67E-4896EAFA AC9E\%7D/resposta_2008.pdf (accessed on 07/ Dec/2008)

6. Lago RF, Costa NR. Dilemas da política de distribuição de medicamentos antiretrovirais no Brasil. Ciênc Saúde Coletiva; in press.

7. Palmeira Filho PL, Pan SSK. Cadeia farmacêutica no Brasil: avaliação preliminar e perspectivas. BNDES Setorial 2003; 18:3-22.
8. Queiroz S, Velazquez AG. Mudanças recentes na estrutura produtiva da indústria farmacêutica. In: Negri B, Di Giovanni G, organizadores. Brasil: radiografia da saúde. Campinas: Universidade de Estadual de Campinas; 2001. p. 123-55.

9. IMS Health. IMS Intelligence 360. http://us.imshea lth.com/i360/ (accessed on 25/Aug/2007).

10. Rêgo ECL. Políticas de regulação do mercado de medicamentos: a experiência internacional. Revista do BNDES 2000; 7:367-400.

11. Bastos VD. Inovação farmacêutica: padrão setorial e perspectivas para o caso brasileiro. BNDES Setorial 2005; 22:271-96.

12. Bastos VD. Laboratórios farmacêuticos oficiais e doenças negligenciadas. Revista do BNDES 2006; 13:269-98.

13. Associação Brasileira Interdisciplinar de AIDS. Por que o Brasil paga mais por medicamentos importantes para a saúde pública? Rio de Janeiro: Associação Brasileira Interdisciplinar de AIDS; 2006.

14. Correa CM. Ownership of knowledge: the role of patents in pharmaceutical R\&D. Bull World Health Organ 2004; 82:784-90.

15. Hasenclever L, Fialho B, Oliveira MA, Oliveira E, Silva HF, Bermudez J. Diagnóstico e papel dos laboratórios públicos na capacitação tecnológica e atividades de P\&D da indústria farmacêutica brasileira. In: Buss PM, Carvalheiro JRC, Casas CPR, org. Medicamentos no Brasil: inovação e acesso. Rio de Janeiro: Editora Fiocruz; 2008. p. 199-231.

16. Baumol WJ, Blinder AS. Economics, principles and policy. Orlando: Sea Dryden Press; 1997. 
17. Stiglitz JE. Economics of the public sector. New York/London: W. W. Norton \& Company; 2000.

18. Gadelha CAG, Quental C, Fialho BC. Saúde e inovação: uma abordagem sistêmica das indústrias da saúde. Cad Saúde Pública 2003; 19:47-59.

19. Marins J, Jamal LF, Chen SY, Barros MB, Hudes ES, Barbosa Jr. A, et al. Dramatic improvement in survival among adult Brazilian AIDS patients. AIDS 2003; 17:1675-82.

20. Ministério do Desenvolvimento Indústria e Comércio Exterior. Lei no 9.279 de 14 de maio de 1996. Regula direitos e obrigações relativos à propriedade industrial. http://www.redetec.org.br/ repict/downloads/Lei\%20da\%20Propriedade\%20I ndustrial.pdf (accessed on 01/Sep/2007).

21. World Trade Organization. Agreement on trade-related aspects of intellectual property rights. http:// www.wto.org/english/tratop_e/trips_e/t_agm0_ e.htm (accessed on 13/Apr/2007).

22. Costa NR, Castro AJW. Custos de transação, estratégias de inovação e produção de medicamentos em laboratórios públicos: o caso do Instituto Tecnológico de Farmanguinhos. Rio de Janeiro: Departamento de Ciências Sociais, Escola Nacional de Saúde Pública, Fundação Oswaldo Cruz; 2007.

23. Programa Nacional de DST e AIDS, Secretaria de Vigilância Sanitária, Ministério da Saúde. O remédio via justiça: um estudo sobre o acesso a novos medicamentos e exames em HIV/Aids no Brasil por meio de ações judiciais. Brasília: Programa Nacional de DST e AIDS, Secretaria de Vigilância Sanitária, Ministério da Saúde; 2005. (Série Legislação, 3).

24. Programa Nacional de DST e AIDS. Brasil decreta licenciamento compulsório do efavirenz. http:// www. aids.gov.br/main.asp?View $=\{$ E77B47C83436-41E0-AC19-E1B215447EB9 $\&$ Team =\&para $\mathrm{ms}=\mathrm{itemID}=\{$ A5D44CBB-5493-4EEE-912E-15DA 572BA68C $\}$; \&UIPartUID $=\{$ D90F22DB-05D4-4644A8F2-FAD4803C8898\} (accessed on 20/May/2007).

25. Levi GC, Vitória MA. Fighting against AIDS: the Brazilian experience. AIDS 2002; 16:2373-83.

26. Galvão J. Brazil and access to HIV/AIDS drugs: a question of human rights and public health. Am J Public Health 2005; 95:1110-6.
27. Frenkel, J. Estudo de competitividade de cadeias integradas no Brasil: impactos das zonas de livre comércio - cadeias farmacêuticas. http://www. desenvolvimento.gov.br/arquivo/sdp/proacao/ forcompetitividade/impzonlivcomercio/42farma ceuticacompleto.pdf (accessed on 03/Apr/2006).

28. Castanhar JC, Barone FM, Motta PR. Avaliação gerencial dos produtores de vacina no Brasil. In: Buss PM, Temporão JG, Carvalheiro JR, org. Vacinas, soros e imunizações no Brasil. Rio de Janeiro: Editora Fiocruz; 2005. p. 245-68.

29. Maçaira LA. A capacitação produtiva brasileira para anti-retrovirais. Abifina Informa 2006; (126).

30. Gadelha CAG. O complexo industrial da saúde e a necessidade de um enfoque na economia da saúde. Ciênc Saúde Coletiva 2003; 8:521-35.

31. Salazar A, Grou KB, Grangeiro A, Fulanetti F, Beloqui J, Scheffer M. Propriedade intelectual, patentes \& acesso universal a medicamentos. São Paulo: Grupo de Incentivo à Vida/Grupo Pela Vidda SP/ Centro de Referência e Treinamento em DST/AIDS de São Paulo/Instituto de Saúde; 2006.

32. Love J. Policies that ensure access to medicine, and promote innovation, with special attention to issues concerning the impact of parallel trade on the competitive sector, and a trade framework to support global R\&D on new health care inventions. In: WTO/WHO Meeting on Differential Pricing \& Financing of Essential Drugs http://www.cptech. org/ip/health/econ/jamie-hosbjor.html (accessed on $20 /$ Oct $/ 2008$ ).

33. Bermudez J, Oliveira MA, Oliveira EA, Chaves GC La propiedad intelectual en el contexto del Acuerdo de la OMC sobre los ADPIC: ¿qué está en juego? In: Bermudez J, Oliveira MA, editores. La propiedad intelectual en el contexto del acuerdo de la OMC sobre los ADPIC: desafíos para la salud pública. Rio de Janeiro: Escola Nacional de Saúde Pública, Fundação Oswaldo Cruz; 2006. p. 25-65.

34. Efavirenz e medicamento importado. Valor Econômico 2007; 25 May.

Received on 18/Mar/2008

Final version resubmitted on $17 / \mathrm{Dec} / 2008$ Approved on 16/Mar/2009 